\title{
RETROSPECTIVE STUDY ON THE PREVALENCE OF COVID-19 CONFIRMED CASES AND EVIDENCE OF GENDER BIAS IN LIBYA
}

Hanan AQEEHAL, Ahmed ALARBI, Haytham MANEEA, Mahmud BENMANSUR, Abdelhadi ELTURKI, Anud ZAABIA, Rachid BENTOUTA, Jebril GEBRIL

National Centre for Disease Control, Ministry of Health, Tripoli, Libya

Corresponding author: Hanan Aqeehal, e-mail: hananaghila@yahoo.com

DOI: $10.38045 /$ ohrm.2022.1.01

CZU: 616.98:578.834.1:614.1(612)

Keywords: SARSCoV-2, comorbidity, clinical symptoms, Libya.

\section{Cuvinte cheie:}

SARS-CoV-2, comorbiditate, simptome clinice, Libia.
Introduction. To stop SARS-CoV-2 from spreading, it's crucial to have a solid understanding of the baseline characteristics of demographic variables, clinical symptoms, and comorbidity so that quarantining and testing protocols can be developed. Material and methods. A retrospective study was conducted on COVID-19 Laboratory confirmed cases. Data were collected by using kobo toolbox, demographic variables, clinical symptoms, and Comorbidity was considered. Yates-corrected chi2 tests and Multinomial Logistic Regression was used to estimate the odds ratio (OR) and 95\% confidence interval (CI) of factors and their impact on COVID-19 prevalence. Results. A total of 6302 of which 3536(56.1\%) men and 2766 (44\%) women with a mean age $( \pm S D)$ of $44 \pm 17$.6 years were included within the study. Clinical symptoms and Comorbidity were significant for both sexes $p<0.0001$. Multinomial Logistic Regression confirmed that age $<55,3$ or more symptoms (OR=1.130 CI95\% 1.013-1.261) and 3 or more comorbidities (OR=1.035 Cl95\% 0.942-1.137) were a significant risk factor for COVID19 prevalence in male patients, among women, age $85>/=, 3$ or more symptoms $(p<0.0001$, OR=1.995 CI95\% 1.335-2.992) and 3 or more comorbidities ( $p<0.0001,0 R=1.538 \mathrm{Cl}$ (95\% 1.045-2.640) were significant risk factor for COVID-19 prevalence in females. Conclusions. Our study suggests that the prevalence of COVID-19 patients and symptoms was higher in men than women. The high prevalence of smoking could have contributed to the high prevalence of COVID-19 among men. Study also suggests that the presence of at least one or combined comorbidities are risk factors of COVID-19 prevalence and a potential risk factor COVID-19 related outcomes. More efforts should be exercised to protect patients with one or more comorbidities from being exposed to infection. \section{STUDIU RETROSPECTIV VIZÂND INCIDENTA CAZURILOR DE COVID -19 CONFIRMATE} ȘI EVIDENȚA BIASULUI DE GEN ÎN LIBIA

Introducere. Pentru a stopa răspândirea SARS-CoV-2, este esențial să fie bine înțelese caracteristicile de bază ale variabilelor demografice, simptomele clinice și comorbiditatea, astfel încât să poată fi dezvoltate protocoale de carantină și de testare. Material și metode. A fost efectuat un studiu retrospectiv pe cazurile confirmate de laboratorul COVID-19. S-au colectat date prin aplicarea Kobo toolbox, luându-se în considerare variabilele demografice, simptomele clinice și comorbiditatea. Pentru a estima riscul relativ (OR), intervalul de în credere de 95\% (CI) al factorilor și impactul acestora asupra prevalenței COVID-19, au fost utilizate Yates corecția pentru testele chi pătrat și regresia logistică multinominală. Rezultate. În studiu au fost incluse 6302 persoane, dintre care 3536 (56,1\%) bărbați și 2766 (44\%) femei, cu vârsta medie $( \pm S D)$ de $44 \pm 17,6$ ani. Simptomele clinice și comorbiditatea au fost semnificative pentru ambele sexe p $<0,0001$. Regresia logistică multinominală a confirmat că vârsta $<55,3$, mai multe simptome (OR=1,130 CI95\% 1,013-1,261), 3 sau mai multe comorbidități $(O R=1,035$ CL95\% 0,942-1,137) au constituit un factor de risc semnificativ pentru prevalența COVID-19 la bărbați, iar în rândul femeilor, vârsta de 85 de ani $>/=, 3$ sau mai multe simptome ( $p<0,0001$, OR=1,995 CI95\% 1,35-2,992), 3 sau mai multe comorbidități ( $p<0,0001$ OR=1,538 CL95\% 1,045-2,640) au prezentat factori de risc semnificativ pentru incidența COVID-19. Concluzii. Studiul constată că prevalența pacienților și a simptomelor COVID-19 a fost mai mare la bărbați decât la femei. Nivelul ridicat al fumatului ar fi putut contribui la incidența înaltă de COVID-19 în rândul bărbaților. Cercetarea noastră sugerează, de asemenea, că prezența a cel puțin uneia dintre comorbidități sau a unor comorbidităților combinate sporește riscul incidenței COVID-19 și se prezintă ca un potențial factor de risc COVID-19rezultatele fiind asociate. Ar trebui să se depună mai multe eforturi în scopul protejării pacienților cu una sau cu mai multe comorbidităţi de expunerea la infecții. 


\section{INTRODUCTION}

On late December, an outbreak of a febrile respiratory illness in Wuhan city, Hubei Province, China (1) caused by the novel coronavirus (2019$\mathrm{nCoV}$ ) or severe acute respiratory syndrome coronavirus 2 (SARS-CoV-2) occurred. The World Health Organization (WHO) identified this disease as novel coronavirus disease 2019 (COVID19) on February 11th, 2020 and declared it a pandemic on March 11th, 2020 (2). As of this writing, the total number of cases documented globally has surpassed 190 million, with over 4 million deaths (3). This fatal infection is spread mostly by large respiratory droplets produced by infected persons when coughing or sneezing, however the virus has also been found in infected people's feces and urine (4). Fever, dry cough, tiredness, nasal congestion, myalgia, sore throat, and diarrhea are the most frequent COVID-19 symptoms, whereas comorbidities include diabetes, hypertension, respiratory illness, cardiovascular disease, cancer, and others $(5,6,7)$. Accordingly, the globe is taking extraordinary efforts to combat the risks presented by the developing pandemic Corona virus (COVID-19). The World Health Organization has declared the coronavirus a global health emergency. As a result, governments and people must take quick action to stop the spread of the illness and safeguard communities. In Libya, the first case diagnosed with COVID-19 (at Tripoli Medical Center) was confirmed by Public Health Reference Laboratory, National Center for Disease Control, Tripoli on March 24th, 2020. Up through December 31st, 2020, the total number of cases has risen by more than 101978 thousand and 1498 Death cases in Libya (8). The knowledge about the characteristics of novel coronavirus is limited, with only few published articles $(9,10)$. However, surveillance officer and the data management team have made remarkable efforts concerning COVID-19 data. The aim of this study is to determine the prevalence of COVID-19 and the impact of variables such as age, comorbidities, clinical features, the frequency of comorbidities on Gender based disparities. The aim of the study is to assess the Gender based disparities in the prevalence of COVID-19 confirmed cases.

\section{MATERIAL AND METHODS}

A retrospective study was conducted on COVID19 Laboratory confirmed cases to gain insight on positive COVID-19 patients characteristics. Variables included the patients' demographic characteristics, comorbidities and symptoms. The completed data was collected by kobo collect toolbox, obtained from the surveillance team who agreed to participate using the kobo toolbox, covering the period from May 5 to December 2020. To display information on comorbidities, symptoms, and other categorical variables, we created frequency tables. To see whether there are any statistically significant variations in categorical variable between males and females, we used Yatescorrected chi ${ }^{2}$ tests for percentages to test gender differences regarding variables. Multinomial Logistic Regression analyses were performed to evaluate the factors associated with confirmed COVID-19 cases, the results were presented as estimated odds ratio (OR) with respective $95 \%$ confidence interval (CI) and $p$ values. A two-sided pvalue $<0.05$ was considered statistically significant. All statistical analyses were performed using Microsoft excel and SPSS version 23 (SPSS Inc., Chicago, IL, USA).

\section{RESULTS}

\section{Characteristics of the sample.}

A total of 6302 patients with a confirmed diagnosis of COVID-19 were identified. Of these, 2766 (44\%) were females and 3536 (56.1\%) were males, the mean age of our sample was $44 \pm 17.6$ years. The $40-59$ age group was the most representative (fig. 1), with a significant difference between men and women $(p<0.05)$ shown in the age groups (10-79) (tab. 1).

\section{Gender differences for clinical features.}

Most men and women COVID-19 confirmed patients manifested asymptomatic development $(52.3 \%)$, with a corresponding sex ratio $(95 \% \mathrm{CI})$ of 1.138 (0.025-0.074), $p=0.0001$ (tab. 2). Regarding the patients with one symptom upon diagnosis , namely breathing difficulties, coughing, diarrhea, high temperature, sore throat and loss of smell and taste, these were significantly more frequently found in men than women, all $\mathrm{p}<0.001$, with sex ratio (95\% CI) of 0.646 (0.785-1.194), whereas patients with two symptoms were also significant $\mathrm{p}<0.05$, sex ratio $(95 \% \mathrm{CI})$ of 1.117 (0.0093-0.393) and patients with three symptoms and more were significant $p<0.05$, with corresponding sex ratio (95\% CI) of 1.134 (0.00580.046) (tab. 3, fig. 2). 
Table 1. Number of COVID-19 cases by age group and sex.

\begin{tabular}{cccc}
\hline Age group & $\begin{array}{c}\text { Male (N, \%) } \\
(\mathbf{N}=\mathbf{3 5 3 6 )}\end{array}$ & $\begin{array}{c}\text { Female (N, \%) } \\
(\mathbf{N}=\mathbf{2 7 6 6 )}\end{array}$ & p-value* \\
\hline $\mathbf{0 - 9}$ & $38(1.1)$ & $47(1.7)$ & 0.5235 \\
\hline $\mathbf{1 0 - 1 9}$ & $185(5.2)$ & $162(5.9)$ & 0.0002 \\
\hline $\mathbf{2 0 - 2 9}$ & $550(15.6)$ & $433(15.7)$ & $\mathrm{p}<0.0001$ \\
\hline $\mathbf{3 0 - 3 9}$ & $839(23.7)$ & $523(18.9)$ & $\mathrm{p}<0.0001$ \\
\hline $\mathbf{4 0 - 4 9}$ & $730(20.6)$ & $547(19.8)$ & $\mathrm{p}<0.0001$ \\
\hline $\mathbf{5 0 - 5 9}$ & $559(15.8)$ & $432(15.6)$ & $\mathrm{p}<0.0001$ \\
\hline $\mathbf{6 0 - 6 9}$ & $357(10.1)$ & $325(11.7)$ & 0.0001 \\
\hline $\mathbf{7 0 - 7 9}$ & $192(5.4)$ & $164(5.9)$ & 0.1555 \\
\hline $\mathbf{2 8 0}$ & $86(2.4)$ & $133(4.8)$ & 0.001 \\
\hline
\end{tabular}

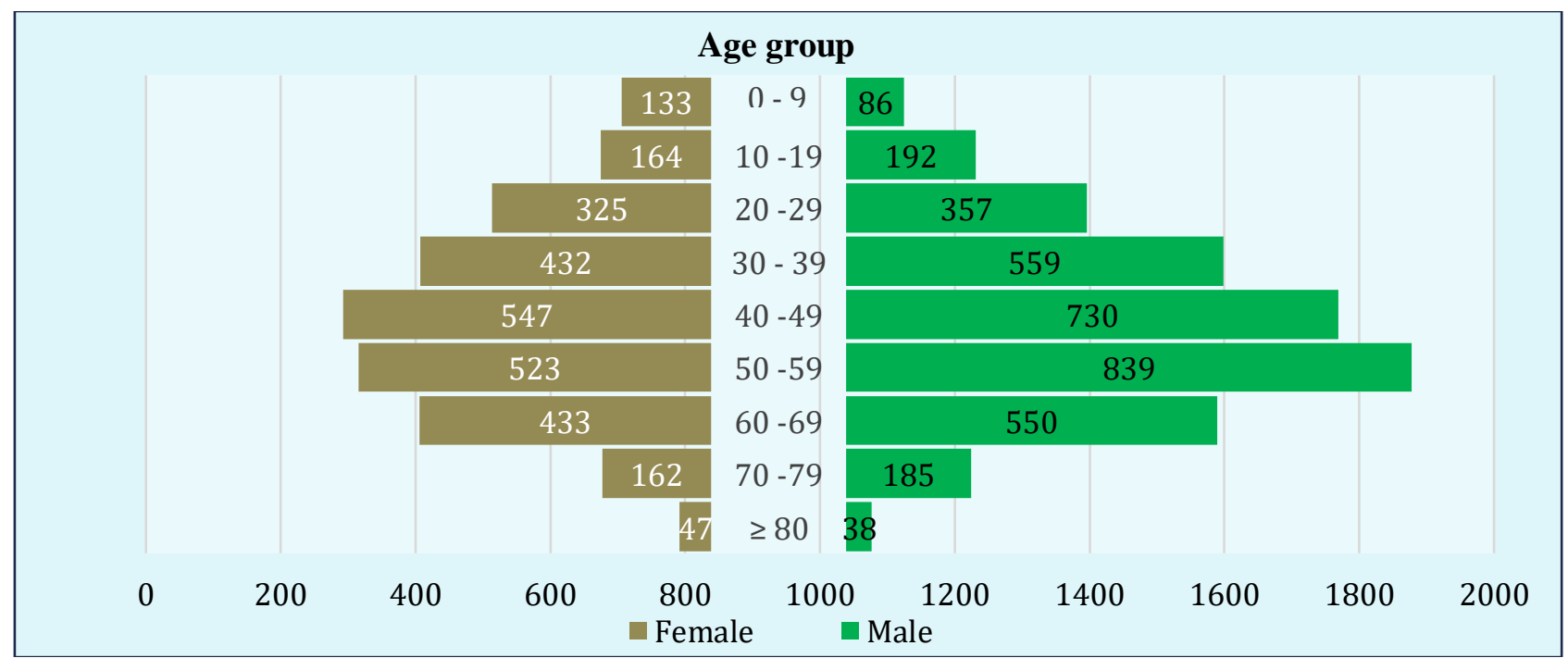

Figure 1. Age and Gender Distribution of COVID-19 patients.

Table 2. Clinical features of COVID-19 patients by gender.

\begin{tabular}{lccccc}
\hline \multicolumn{1}{c}{ Signs and Symptoms } & $\begin{array}{c}\text { Female } \\
(\mathbf{N}=\mathbf{2 7 6 6})\end{array}$ & $\begin{array}{c}\text { Male } \\
(\mathbf{N}=\mathbf{3 5 3 6 )}\end{array}$ & $\begin{array}{c}\text { Sex } \\
\text { ratio }\end{array}$ & $\mathbf{9 5 \% C I}$ & p-value* $^{\text {95\% }}$ \\
\hline Patients with no symptoms & $1133(41)$ & $1273(36)$ & 1.138 & $0.025-0.074$ & 0.0001 \\
\hline 1 symptom & $500(18.1)$ & $990(28)$ & 0.646 & $0.785-1.194$ & $\mathrm{p}<0.0001$ \\
\hline 2 Symptoms & $526(19)$ & $587(17)$ & 1.117 & $0.0093-0.393$ & 0.0398 \\
\hline 3 Symptoms or more & $607(22)$ & $686(19.4)$ & 1.134 & $0.0058-0.046$ & 0.0112 \\
\hline
\end{tabular}

Table 3. Prevalence of COVID-19 symptoms.

\begin{tabular}{lccc}
\hline \multicolumn{1}{c}{ Signs and Symptoms } & $\begin{array}{c}\text { Female } \\
(\mathbf{N = 2 7 6 6 )}\end{array}$ & $\begin{array}{c}\text { Male } \\
(\mathbf{N = 3 5 3 6 )}\end{array}$ & p-value* \\
\hline Patients with no symptoms & $1365(59)$ & $1930(55)$ & 0.0015 \\
\hline Breathing difficulties & $17(0.61)$ & $21(0.59)$ & 0.9149 \\
\hline Cough & $78(2.82)$ & $83(2.35)$ & 0.2386 \\
\hline Diarrhea & $16(0.57)$ & $19(0.54)$ & 0.873 \\
\hline High temperature & $94(3.4)$ & $129(3.6)$ & 0.668 \\
\hline Sore throat & $15(0.54)$ & $19(0.54)$ & 0.978 \\
\hline Loss of the sense of smell and taste & $48(1.73)$ & $62(1.75)$ & 0.952 \\
\hline 2 symptoms & $526(19.1)$ & $587(16.6)$ & 0.009 \\
\hline 3 or more symptoms & $607(21.9)$ & $686(19.4)$ & 0.015 \\
\hline
\end{tabular}




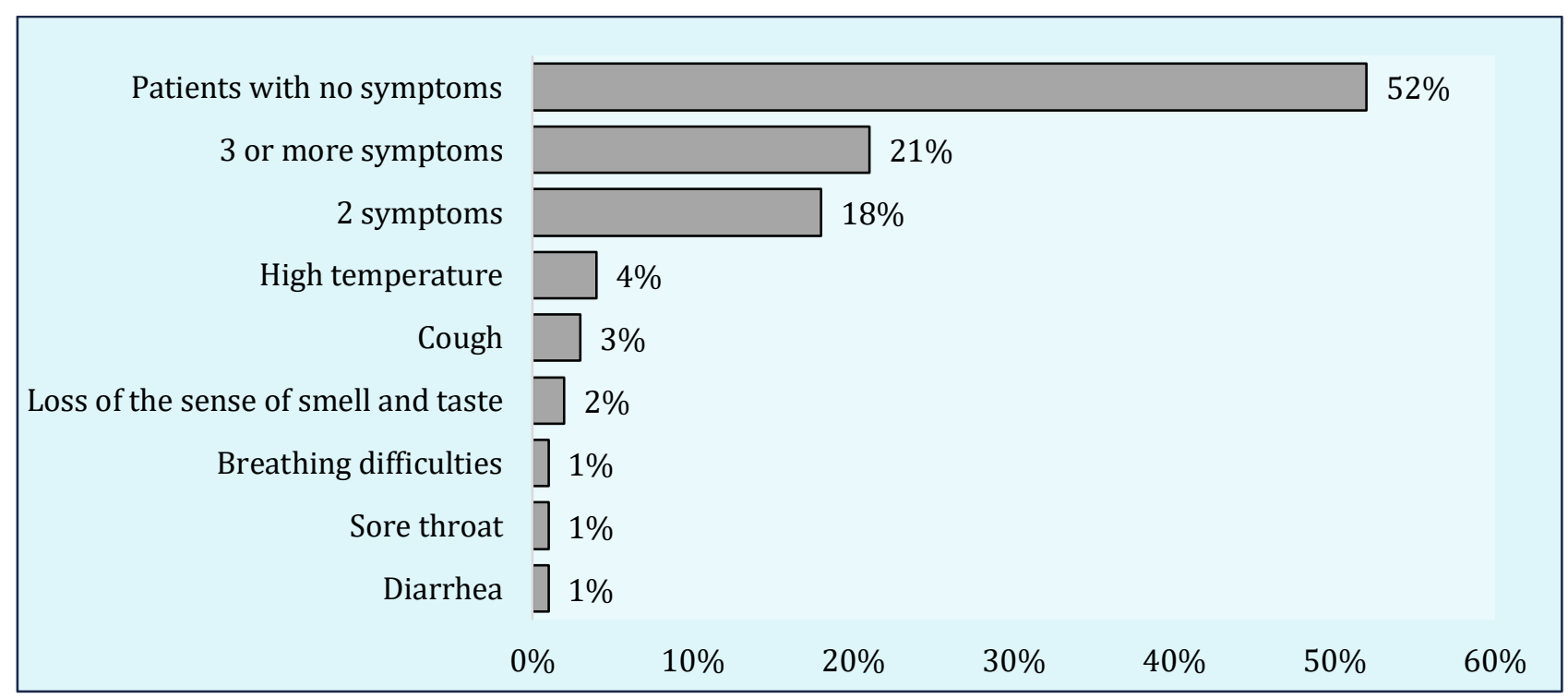

Figure 2. Prevalence of COVID-19 symptoms.

\section{Gender differences of comorbidity upon diag-} nosis.

COVID-19 confirmed cases in patients with No comorbidity were $33 \%$, and the percentages were comparable (35\% for men and 31\% for women), with a corresponding sex ratio $(95 \% \mathrm{CI})$ of 0.886 (0.017-0.632) $\mathrm{p}<0.0001 .12 \%$ of the patients $(n=770)$ were diagnosed with COVID 19 and had one comorbidity, with significant difference between men to women $(14 \%$ vs. $11 \%$, respectively), with sex ratio $(95 \% \mathrm{CI})$ of $0.786(0.0569$ 0.0835 ) $\mathrm{p}<0.0001$ (tab. 4). Furthermore, asthma, hypertension, diabetes and obesity were shown to be significant; similarly in women to add pregnancy (tab. 5). Moreover, there was a significant difference between men to women $\mathrm{p}<0.0001$ with two comorbidities in COVID-19 patients and the percentages were comparable $26.5 \%$ for men and $28 \%$ for women), with sex ratio $(95 \% \mathrm{CI})$ of 1.057 (0.0017-0.037). Among n=1742 COVID-19 confirmed patients, those with three or more comorbidities showed a significant difference between men to women $(25.1 \%$ vs. $31 \%$, respectively), with sex ratio $(95 \% \mathrm{CI})$ of 1.235 (0.3660.814 ) $\mathrm{p}<0.0001$ (tab. 6).

Table 4. Comorbidity of COVID-19 patients upon diagnosis.

\begin{tabular}{lccccc}
\hline \multicolumn{1}{c}{ Comorbidity } & $\begin{array}{c}\text { Female } \\
(\mathbf{N = 2 7 6 6 )}\end{array}$ & $\begin{array}{c}\text { Male } \\
(\mathbf{N = 3 5 3 6 )}\end{array}$ & $\begin{array}{c}\text { Sex } \\
\text { ratio }\end{array}$ & 95\%CI & p-value* \\
\hline Patients with no Comorbidity & $854(31)$ & $1235(35)$ & 0.886 & $0.017-0.632$ & 0.0008 \\
\hline 1 Comorbidity & $291(11)$ & $479(14)$ & 0.786 & $0.0569-0.0835$ & $\mathrm{p}<0.0001$ \\
\hline 2 Comorbidities & $765(28)$ & $936(26.5)$ & 1.057 & $0.0017-0.037$ & 0.0004 \\
\hline 3 Comorbidities or more & $856(31)$ & $886(25.1)$ & 1.235 & $0.366-0.814$ & $\mathrm{p}<0.0001$ \\
\hline
\end{tabular}

Multinomial logistic regression model of the factors predicting the contribution in the prevalence's of COVID-19 in both male and female revealed the following the predictors: age $(<55,55$ to $<85,>/=85$ ), symptoms (No symptoms, 1 to 3 symptoms) and comorbidity (No comorbidity, 1 to 3 comorbidities) (tab. 6). In the gender-specific analysis, among men, $(<55,55$ to $<85,>/=85)$, no symptoms, 1 - 3 symptoms, no comorbidity, more than 3 comorbidities; asthma, hypertension, diabetes and obesity were associated with a higher rate of COVID-19 prevalence (fig. 3). Similarly, among women, age ( 55 to $<85,>/=85$ ), symptoms ( 1 to 3 symptoms) and comorbidity (No comorbidity, 1 to 3 comorbidities); asthma, hypertension, diabetes, obesity, and pregnancy were associated with a higher rate of COVID-19 prevalence (fig. 4). 
Table 5. Prevalence of Comorbidity.

\begin{tabular}{lccc}
\hline \multicolumn{1}{c}{ Risk factors and comorbidity } & $\begin{array}{c}\text { Female } \\
(\mathbf{N}=\mathbf{2 7 6 6 )}\end{array}$ & $\begin{array}{c}\text { Male } \\
(\mathbf{N}=\mathbf{3 5 3 6})\end{array}$ & p-value* \\
\hline Patients with no Comorbidity & $752(27.2)$ & $1050(30)$ & 0.015 \\
\hline Asthma & $34(1.23)$ & $10(0.28)$ & $\mathrm{p}<0.0001$ \\
\hline Cancer & $6(0.23)$ & $6(0.17)$ & 0.6642 \\
\hline Cardiovascular disease & $27(0.98)$ & $40(1.13)$ & 0.5647 \\
\hline HIV & $2(0.1)$ & $0(0)$ & 0.0600 \\
\hline Hypertension & $130(5)$ & $93(2.63)$ & $\mathrm{p}<0.0001$ \\
\hline Kidney disease & $21(0.76)$ & $17(0.5)$ & 0.1899 \\
\hline Diabetes & $102(4)$ & $185(5.2)$ & 0.025 \\
\hline Obesity & $25(0.9)$ & $11(0.31)$ & 0.0020 \\
\hline Pregnancy & $45(1.62)$ & $0(0)$ & $\mathrm{p}<0.0001$ \\
\hline Rheumatism & $1(0.036)$ & $0(0)$ & 0.2592 \\
\hline Other disease (irritable bowel syndrome) & $0(0)$ & $1(0.028)$ & 0.7808 \\
\hline Epilepsy & $0(0)$ & $1(0.028)$ & 0.7808 \\
\hline Smoke & $0(0)$ & $300(8.5)$ & $\mathrm{p}<0.0001$ \\
\hline 2 Comorbidities & $765(28)$ & $936(26.5)$ & 0.0004 \\
\hline 3 Comorbidities or more & $856(31)$ & $886(25.1)$ & $\mathrm{p}<0.0001$ \\
\hline
\end{tabular}

Table 6. Multinomial logistic regression results for prominent character gender $(n=6302)$.

\begin{tabular}{|c|c|c|c|c|c|c|c|c|}
\hline \multirow[b]{2}{*}{ Characteristics } & \multicolumn{4}{|c|}{ Female $(n=2766)$} & \multicolumn{4}{|c|}{ Male $(n=3536)$} \\
\hline & B & S. E & $\begin{array}{l}\text { Odd ra- } \\
\text { tio [OR] }\end{array}$ & $95 \% \mathrm{CI}$ & B & S. E & $\begin{array}{l}\text { Odd ra- } \\
\text { tio [OR] }\end{array}$ & $95 \% \mathrm{CI}$ \\
\hline \multicolumn{9}{|l|}{ Age category } \\
\hline$<55$ & 0.199 & 0.076 & 1.220 & $1.051-1.416$ & 0.310 & 0.030 & $1.364^{* * *}$ & $1.28-1.446$ \\
\hline 55 to $<85$ & 0.424 & 0.085 & $1.529 * * *$ & $1.294-1.806$ & 0.085 & 0.051 & $1.089^{* * *}$ & $0.986-1.203$ \\
\hline$>/=85$ & 0.691 & 0.205 & $1.995^{* * *}$ & $1.335-2.982$ & 0.199 & 0.191 & $0.820^{* * *}$ & $0.564-1.191$ \\
\hline \multicolumn{9}{|l|}{ Symptoms } \\
\hline $\begin{array}{l}\text { Patients with no } \\
\text { symptoms }\end{array}$ & 0.133 & 0.072 & 1.142 & $0.991-1.316$ & 0.117 & 0.041 & $1.124^{*}$ & $1.037-1.217$ \\
\hline 1 symptom & -0.706 & 0.082 & $0.494^{* * *}$ & $0.420-($ & 0.68 & 0.055 & $2.025^{* * *}$ & $1.724-2.479$ \\
\hline 2 Symptoms & 0.061 & 0.083 & 1.063 & $0.903-$ & 0.110 & 0.060 & 1.116 & $0.992-1.255$ \\
\hline $\begin{array}{l}3 \text { Symptoms or } \\
\text { more }\end{array}$ & 0.287 & 0.073 & $1.995^{*}$ & $1.335-2.992$ & 0.122 & 0.056 & $1.130^{*}$ & $1.013-1.261$ \\
\hline \multicolumn{9}{|l|}{ Comorbidity } \\
\hline $\begin{array}{l}\text { Patients with no } \\
\text { Comorbidity }\end{array}$ & -0.360 & 0.074 & $0.691^{* * *}$ & $0.634-0.755$ & 0.369 & 0.045 & $1.446^{* * *}$ & $1.325-1.578$ \\
\hline 1 Comorbidity & -0.422 & 0.093 & $0.608^{* * *}$ & $0.525-0.703$ & 0.498 & 0.074 & 1.646 & $1.423-1.904$ \\
\hline 2 Comorbidity & 0.111 & 0.073 & 0.895 & $0.743-0.899$ & 0.202 & 0.049 & 1.224 & $1.112-1.346$ \\
\hline $\begin{array}{l}3 \text { Comorbidity or } \\
\text { more }\end{array}$ & -0.034 & 0.048 & $1.538^{* * *}$ & $1.045-2.640$ & 0.034 & 0.048 & $1.035^{* * *}$ & $0.942-1.137$ \\
\hline
\end{tabular}

S.E $=$ Standard Error

$\mathrm{OR}=$ odds ratios
$\mathrm{CI}=$ confidence interval

${ }^{*} \mathrm{p}<.05,{ }^{* *} \mathrm{p}<.01,{ }^{* * *} \mathrm{p}<.001$ 


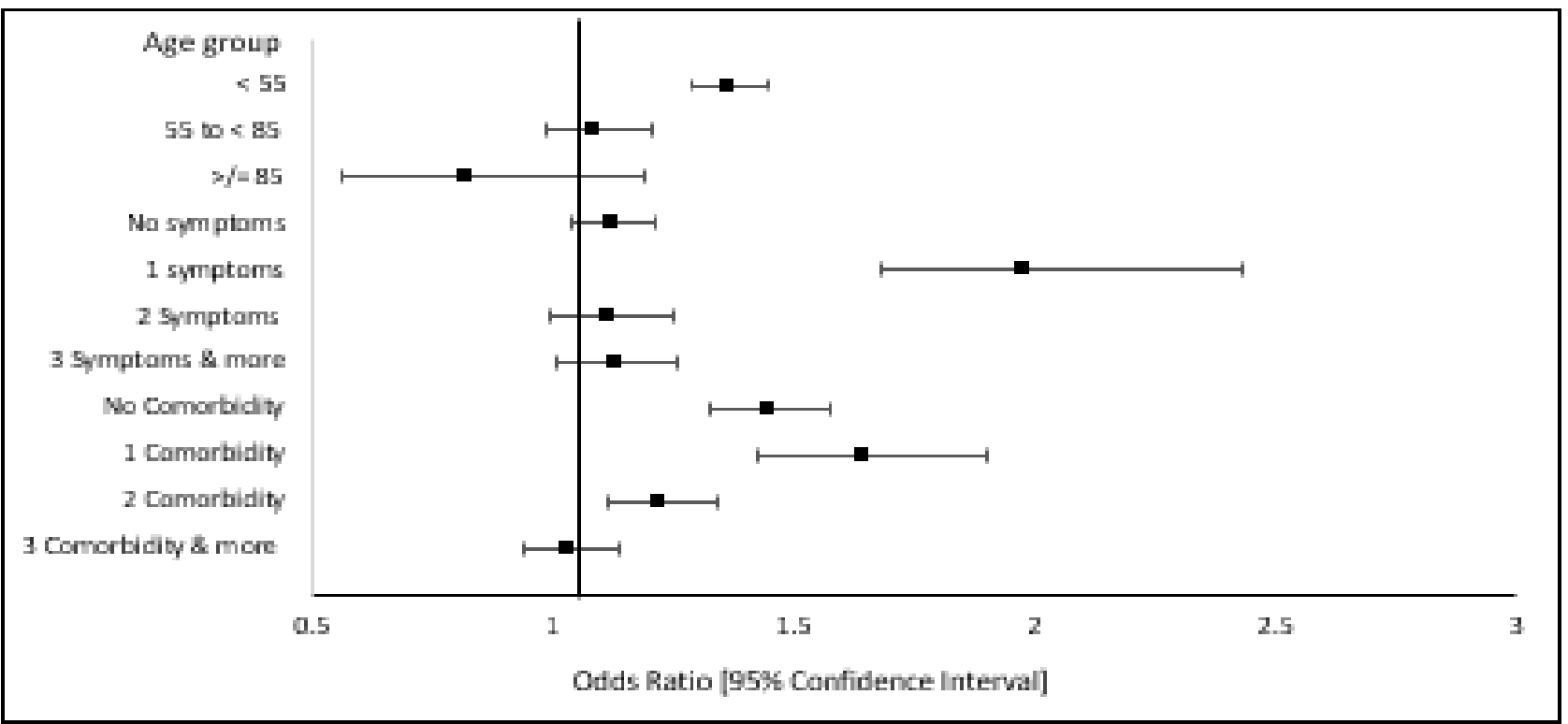

Figure 3. Forrest plot of the odds ratio and confidence intervals calculated for each variable found to be independently associated with prevalence of COVID -19 among male patients.

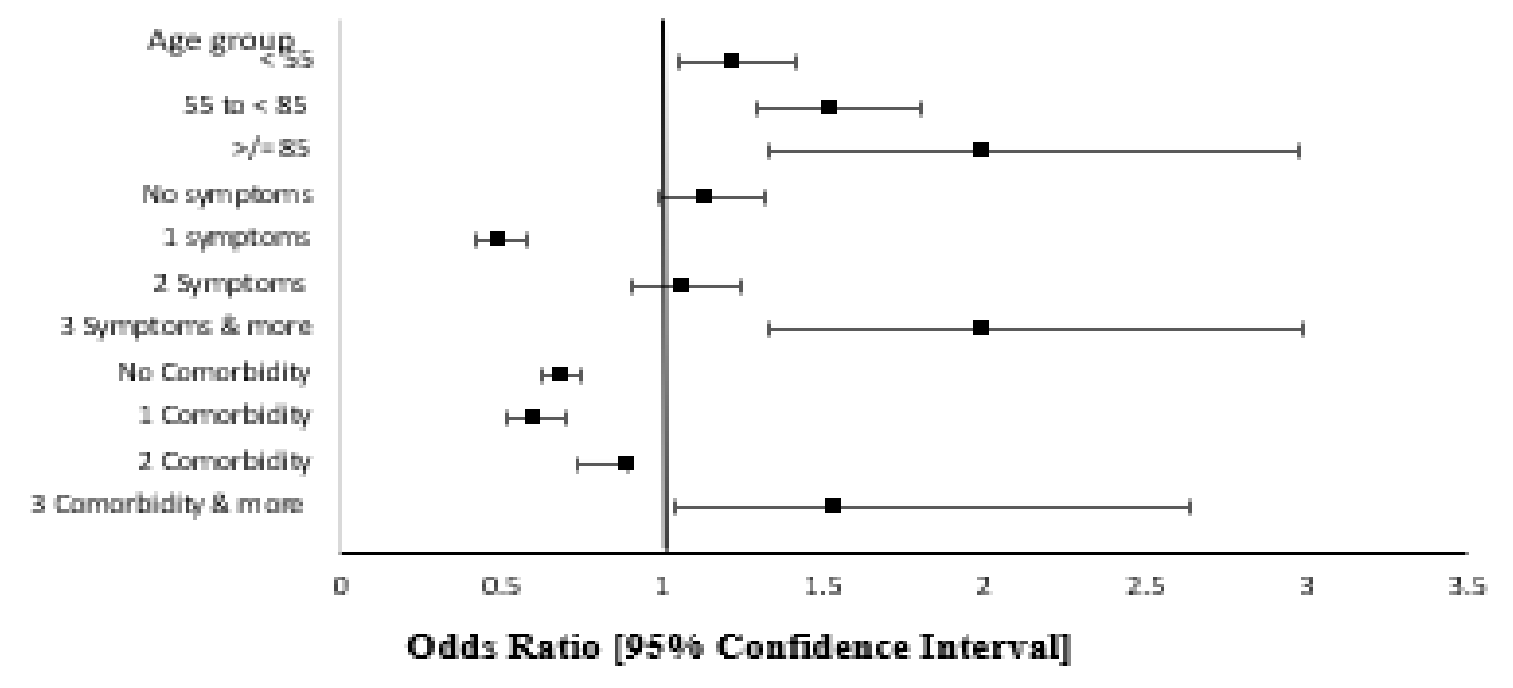

Figure 4. Forrest plot of the odds ratio and confidence intervals calculated for each variable found to be independently associated with prevalence of COVID-19 among Female patients.

\section{DISCUSSIONS}

Libya, like many other countries, is going through a challenging time because of the global COVID-19 issue. Furthermore, since the beginning of the war in Libya in early $2011(11,12,13)$, the nation has experienced internal security, political, and economic crises, in addition to the looming health catastrophe in 2020. Therefore, the ability to cope with pandemic data and health information was limited.

However, according to this study, the use of a sim ple data collection tool like the kobo gather toolbox aided the surveillance officer in collecting COVID-19 data. In previous research conducted in several countries focusing on patients' demographics, underlying health comorbidities, socioeconomic inequities in healthcare access and quality, and environmental variables including pollution, to identify possible risk factors and susceptible groups, while other researches have looked over the impacts of these domains on COVID-19 dissemination individually, some of them haven't considered the possibly confusing 
interactions between factors. On the other hand, according to our knowledge there are limitations regarding risk factors related to COVID-19 researches in Libya. However, one study was done to explore the factors that influence in-ICU mortality rate, which revealed that risk factors such as age, BMI, laboratory findings, admission SOFA score, and quick SOFA score were strongly predictive for mortality (9). In this study, we sought to investigate the COVID-19 prevalence and their association with demographical characteristics, clinical manifestation, and comorbidities, we observed that males are more likely to be infected by COVID-19 (with 56.1\%) compared to females (44\%). A similar conclusion has previously been observed in another research $(14,15,16)$. Men are more vulnerable than women, according to research carried out in Spain (17), because of their careless attitude about the possibility of a COVID-19 pandemic. Another Spanish study found that males and the elderly have a greater severity and case fatality rate (CFR) (18). Furthermore, females have stronger resistance, which might be attributed to female sex hormones, whereas men have lesser resistance owing to the high expression of the ACE2 receptor, which coronavirus easily attaches to (19). Other studies also showed that higher viral load in men has also been linked to ACE2 expression, reduced B cell and NK cell-specific transcripts, male hormones, and enhanced NF-B inhibitor $(20,21,22)$. Results showed that all age groups in both sexes were susceptible to COVID-19, showing a significant difference of $\mathrm{p}<0.0001$, however younger individuals aged between 0-19-70+ showed lower COVID-19 incidence, while higher rate of COVID19 cases was noticed in age groups over 20 years (aged 20-69). Furthermore this could indicate that during this study period from May to December 2020, the COVID-19 virus had the Wuhan strain, and the susceptibility to contract the virus among men or women may depend on the role of biological profile of a person; as well as their activities, were men are more likely to engage in outside activities, exposing them to conditions such as extreme weather and pollution, which might influence their response to an infection such as COVID-19. Furthermore, men's lifestyles, which include smoking, result in a high viral load and severity (23). In our study, smoking was significant $\mathrm{p}<0.0001$ in male patients, thus our findings were similar to a study which suggested that those current smokers are at greater risk than former smokers or non-smokers (24).

The prevalence of clinical symptoms among 6302 COVID-19 cases, 3896 (62\%) were symptomatic and asymptomatic $38.2 \%$ and about $25 \%$ had one clinical symptom (high temperature, coughing, breathing difficulties, diarrhea, sore throat, loss of smell and taste), $18 \%$ with two symptoms and $21 \%$ with three or more symptoms. Therefore, our results on the prevalence of symptoms in adults corresponded to the results found in systemic literature review $(25,26)$. The findings show clearly that fever and cough are the most common symptoms, while other symptoms occur at much lower prevalence. However, there was not enough evidence on the prevalence of additional symptoms difference by age in the young and adults.

The presence of comorbidities in 67\% of COVID19 cases; with $33 \%$ had no comorbidity, $12.2 \%$ reported having at least one comorbidity, $27 \%$ had two comorbidities and $28 \%$ had reported three or more comorbidities. Furthermore, in the study the prevalence of specific comorbidities for both sexes included diabetes, hypertension, cardiovascular diseases, asthma, and obesity with $\mathrm{p}<0.0001$. In pregnant women the significant value was of $p<0.0001$, thus the studies suggested that pregnancy has been identified as a risk factor for developing severe complications $(27,28)$. The study findings are consistent with other published studies $(29,30)$. However, few data were available on the frequency of combinations of comorbidities and symptoms $(31,32)$. The Multinomial Logistic Regression confirmed the age $<55$ $(\mathrm{p}<0.0001, \mathrm{OR}=1.364$ CI95\% 1.287-1.446), 3 or more symptoms $(\mathrm{p}<0.0001, \mathrm{OR}=1.130 \quad \mathrm{CI} 95 \%$ 1.013-1.261) and 3 or more comorbidity $(\mathrm{p}<0.0001, \mathrm{OR}=1.035 \mathrm{Cl} 95 \% 0.942-1.137)$ was a significant risk factor for COVID-19 prevalence in male patients, whereas women, was significant with age $85>/=(\mathrm{p}<0.0001,0 \mathrm{O}=1.995$ (1.3352.982), 3 or more symptoms $(\mathrm{p}<0.0001$, OR=1.995 CI95\% $1.335-2.992$ ) and 3 or more comorbidity $(\mathrm{p}<0.0001, \mathrm{OR}=1.538 \mathrm{Cl} 95 \% 1.045$ 2.640). Our findings were similar in a meta- analysis study $(25,29,32)$. Furthermore, our findings suggested that patients with comorbidities are more likely to have poorer well-being. Therefore, proper triage of patients should be implemented by carefully inquiring about their medical history; both the category and number of comorbidities should be considered because it might help iden 
tify patients who would be more likely to develop adverse outcomes of COVID-19 and predicting the prognosis in patients with COVID-19. Moreover, better protection should be given to the patients with COIVD-19 who had comorbidities upon confirmation of the diagnosis.

Although this study highlights the prevalence COVID-19-related symptoms, comorbidities limi- tations must be acknowledged. The sample size was small, but most results were consistent with other studies on adults and children's patients with COVID-19. The study did not include data on the recovered COVID-19 patients. Furthermore, this study didn't evaluate the mortality rate in patients with severe COVID-19, thus a larger case series should be considered for further analysis.

\section{CONCLUSIONS}

1. Available data indicate that the prevalence of COVID-19 patients is greater in males than in women, and that vulnerability to COVID-19 cases among young and middle-aged people is similar to that of older age groups.

2. The prevalence of COVID-19 symptoms was found to be higher in men than in women. The high prevalence of smokers might contribute to the high prevalence of COVID-19 among men.

3. Our study also suggests that the presence of at least one or combined comorbidities represent risk factors of COVID-19 prevalence and a potential risk factor for COVID-19-related outcomes. More efforts should be implemented to protect patients with one or more comorbidities from being exposed to the infection.

\section{CONFLICT OF INTERESTS}

Authors declare no conflict of interests.

\section{REFERENCES}

1. Hui DS, Azhar EI, Madani TA, Ntoumi F, Kock R, Dar O, Ippolito G, Mchugh TD, Memish ZA, Drosten C, Zumla A. The continuing 2019-nCoV epidemic threat of novel coronaviruses to global health-The latest 2019 novel coronavirus outbreak in Wuhan, China. International Journal of Infectious Diseases. 2020; 91:264-6.

2. "WHO Director-General's opening remarks at the media briefing on COVID-19 - 11 March 2020". World Health Organization (WHO) (Press release). 11 March 2020. Archived from the original on 11 March 2020. Retrieved 12 March 2020.

3. Coronavirus Disease (COVID-19): Weekly Epidemiological Update (20 July 2021) Available from: https://reliefweb.int/report/world/coronavirusdisease-covid-19-weekly-epidemiological-update-20-july-2021 [Accessed: 20 July 2021].

4. Gupta R, Ghosh A, Singh AK, Misra A. Clinical considerations for patients with diabetes in times of COVID-19 epidemic. Diabetes \& Metabolic Syndrome. 2020;14(3):211.

5. Fisher D, Heymann D. Q\&A: the novel coronavirus outbreak causing COVID-19. BMC Med. 2020;18(1):57.

6. Rodriguez-Morales AJ, Cardona-Ospina JA, Gutiérrez-Ocampo E. Clinical, laboratory and imaging features of COVID-19: a systematic review and meta-analysis. Travel Med. Infect. Di. 2020; 34:101623.

7. Guan W-J, Liang W-H, Zhao Y. Comorbidity, and its impact on 1590 patients with COVID-19 in China: a nationwide analysis. Eur. Respir. J. 2020;55(5):2000547.

8. COVID-19 LIBYA. Available from: https://www. facebook.com/NCDC.LY/posts/ 2845518905719315 [Accessed: 1 January 2021].

9. Elhadi M, Alsoufi A, Abusalama A, Alkaseek A, Abdeewi S, Yahya M, et al. Epidemiology, outcomes, and utilization of intensive care unit resources for critically ill COVID-19 patients in Libya: A prospective multi-center cohort study. Plos One. 2021;16(4):e0251085.

10. Zarmouh A, Elaswdi H, Elakhtel E, Abufalgha K, Taraina M. Epidemiology of COVID-19 in Misrata, Libya: A Population-Based Surveillance Study. Open Journal of Epidemiology. 2021;11(01):101.

11. Polo SM. A pandemic of violence? The impact of COVID-19 on conflict. Peace Economics, Peace Science and Public Policy. 2020;26(3).

12. COVID-19 Pandemic Humanity needs leadership and solidarity to defeat COVID-19. Available from: https://www.ly.undp.org/content/libya/en/home/coronavirus.html [Accessed: 2 February 2021].

13. Daw MA, El-Bouzedi AH, Ahmed MO, Alejenef AA. The epidemiological characteristics of COVID-19 in Libya during the ongoing-armed conflict. The Pan African Medical Journal. 2020;37.

14. Bwire GM. Coronavirus: why men are more vulne nerable to Covid-19 than women? SN - Compre- 
hensive Clinical Medicine. 2020;2(7):874-6.

15. Conti P, Younes A. Coronavirus COV-19/SARSCoV-2 affects women less than men: clinical response to viral infection. J Biol Regul Homeost Agents. 2020;34(2):339-43.

16. Hu D, Lou X, Meng N, Li Z, Teng Y, Zou Y, Wang F. Influence of age and gender on the epidemic of COVID-19. Wiener Klinische Wochenschrift. 2021; 133(7):321-30.

17. De La Vega R, Ruíz-Barquín R, Boros S, Szabo A. Could attitudes toward COVID-19 in Spain render men more vulnerable than women? Global Public Health. 2020;15(9):1278-91.

18. Moraga P, Ketcheson DI, Ombao HC, Duarte CM. Assessing the age-and gender-dependence of the severity and case fatality rates of COVID-19 disease in Spain. Wellcome Open Research. 2020;5.

19. Bwire G.M. Coronavirus: why men are more vulnerable to covid-19 than women? SN Compr. Clin. Med. 2020;2:874-876.

20. Lieberman NA, Peddu V, Xie H. In vivo antiviral host transcriptional response to SARS-CoV-2 by viral load, sex, and age. PLoS Biol. 2020;18(9).

21. Moeser A. COVID-19 Affects Men More than Women and This Could Be the Reason Why, According to Scientists. Available from: https:// www.weforum.org/agenda/2020/06/covid19mortality-rates-men-women/ [Accessed: 9 June 2020].

22. Lee J, Yousaf A, Fang W, Kolodney MS. Male balding is a major risk factor for severe COVID-19. J. Am. Acad. Dermatol. 2020; S0190-9622(20):3226232263.

23. Smoking and COVID-19. World Health Organization, 2020. Available from: https://www. who.int/news-room/commentaries/detail/smoking-and-covid-19 [Accessed: 30 June 2020].

24. Alqahtani JS, Oyelade T, Aldhahir AM. Prevalence, severity, and mortality associated with COPD and smoking in patients with COVID-19: a rapid systematic review and meta-analysis. PloS One.

Date of receipt of the manuscript: $27 / 10 / 2021$ Date of acceptance for publication: 11/12/2021

Hanan AQEEHAL, ORCID ID: 0000-0003-0601-7009 Ahmed ALARBI, ORCID ID: 0000-0002-8341-4174 Haytham MANEEA, ORCID ID: 0000-0003-1416-8851 Mahmud BENMANSUR, ORCID ID: 0000-0001-5239-2657 Abdelhadi ELTURKI, ORCID ID: 0000-0002-1283-3953 Anud ZAABIA, ORCID ID: 0000-0003-3347-3720 Rachid BENTOUTA, ORCID ID: 0000-0002-5919-2452 Jebril GEBRIL, ORCID ID: 0000-0002-4500-7834
2020;15(5).

25. Barek MA, Aziz MA, Islam MS. Impact of age, sex, comorbidities, and clinical symptoms on the severity of COVID-19 cases: A meta-analysis with 55 studies and 10014 cases. Heliyon. 2020;6(12): e05684.

26. Grant MC, Geoghegan L, Arbyn M, Mohammed Z, McGuinness L, Clarke EL, Wade RG. The prevalence of symptoms in 24,410 adults infected by the novel coronavirus (SARS-CoV-2; COVID-19): a systematic review and meta-analysis of 148 studies from 9 countries. Plos One. 2020;15(6): e0234765.

27. Phoswa WN, Khaliq OP. Is pregnancy a risk factor of COVID-19? European Journal of Obstetrics \& Gynecology and Reproductive Biology. 2020; 252:605-9.

28. Jafari M, Pormohammad A, Sheikh Neshin SA, Ghorbani S, Bose D, Alimohammadi S, et al. Clinical characteristics and outcomes of pregnant women with COVID-19 and comparison with control patients: A systematic review and meta-analysis. $R e$ views in medical virology. 2021;2:e2208.

29. Guan WJ, Liang WH, Zhao Y, Liang HR, Chen ZS, Li YM, et al. Comorbidity and its impact on 1590 patients with COVID-19 in China: a nationwide analysis. European Respiratory Journal. 20201;55(5).

30. Alanazi KH, Abedi GR, Midgley CM, et al. Diabetes mellitus, hypertension, and death among 32 patients with MERS-CoV infection, Saudi Arabia. Emerg Infect Dis. 2020; 26:166-168.

31. Bajgain KT, Badal S, Bajgain BB, Santana MJ. Prevalence of comorbidities among individuals with COVID-19: A rapid review of current literature. American Journal of Infection Control. 2021;49(2):238-46.

32. Alali AS, Alshehri AO, Assiri A, Khan S, Alkathiri MA, Almohammed OA, et al. Demographics, Comorbidities, and Outcomes among Young and Middle-Aged COVID-19 Patients in Saudi Arabia. Saudi Pharmaceutical Journal. 2021;833-842. doi:10.1016/j.jsps.2021.06.005 